Article

\title{
Efficient Chemo-Enzymatic Flow Synthesis of High Value Amides and Esters
}

\author{
Francesca Annunziata ${ }^{1}$, Martina Letizia Contente ${ }^{2}$, Daniele Betti ${ }^{1}$, Cecilia Pinna ${ }^{1}$, \\ Francesco Molinari ${ }^{3}$, Lucia Tamborini ${ }^{1, *(D)}$ and Andrea Pinto ${ }^{3}$ (D) \\ 1 Department of Pharmaceutical Sciences (DISFARM), University of Milan, via Mangiagalli 25, 20133 Milan, \\ Italy; francesca.annunziata@unimi.it (F.A.); daniele.betti@unimi.it (D.B.); cecilia.pinna@unimi.it (C.P.) \\ 2 School of Chemistry, University of Nottingham, University Park, Nottingham NG7 2RD, UK; \\ martina.contente@nottingham.ac.uk \\ 3 Department of Food, Environmental and Nutritional Sciences (DeFENS), University of Milan, via Celoria 2, \\ 20133 Milan, Italy; francesco.molinari@unimi.it (F.M.); andrea.pinto@unimi.it (A.P.) \\ * Correspondence: lucia.tamborini@unimi.it; Tel.: +39-025-031-9367
}

Received: 18 July 2020; Accepted: 14 August 2020; Published: 16 August 2020

\begin{abstract}
A flow-based chemo-enzymatic synthesis of selected APIs (i.e., butacaine, procaine and procainamide) has been developed. A bioreactor made of MsAcT, a versatile acyltransferase from Mycobacterium smegmatis, immobilised on glyoxyl-garose, was exploited to efficiently prepare amide and ester intermediates in gram scale. Immobilised MsAcT was employed in pure organic solvent, demonstrating high stability and reusability. In-line purification of the key intermediates using polymer-bound sulphonyl chloride was added after the bioreactor, enhancing the automation of the process. A final hydrogenation step using the H-Cube reactor was further carried out to obtain the selected APIs in excellent yields (>99\%), making the process fast, safe and easily handled.
\end{abstract}

Keywords: flow chemistry; biocatalysis; immobilisation; active pharmaceutical ingredients; flow hydrogenation

\section{Introduction}

Continuous flow synthesis of fine chemicals, such as drug substances and active pharmaceutical ingredients (APIs), is expanding rapidly in industrial contexts [1-3]. At the same time, biocatalysis is now considered one of the most promising technologies for sustainable processing in chemistry [4-6], and the combination of biocatalysis and flow chemistry has emerged as an important opportunity to expand the chemical toolbox for synthetic chemistry under environmentally benign conditions [7-10]. In this context, the development of chemo-enzymatic flow-based routes represents an innovative strategy for the obtainment of APIs by combining the advantages of the flexibility of chemical reactions with the high efficiency, regio-, chemo- and stereo-selectivity of enzymatic biotransformations [11-15].

We recently exploited the immobilised acyltransferase from Mycobacterium smegmatis (MsAcT) for efficiently catalysing ester and amide formation in aqueous phases under flow conditions starting from primary alcohols or amines and short-chain esters [16,17]. In the present work, the catalytic power of MsAcT was also demonstrated using vinyl 4-nitrobenzoate as acyl donor in pure organic solvent. This feature appears highly beneficial to guarantee a good solubility for lipophilic substrates to achieve more productive protocols. In particular, we focused on the biocatalysed flow synthesis of amide or ester intermediates useful for the synthesis of three APIs, i.e., the antiarrhythmic procainamide (1), and the local anesthetics procaine (2) and butacaine (3), that were isolated in good yields after flow hydrogenation reaction (Figure 1). Common strategies for the obtainment of these APIs typically require anhydrous reaction environment, stoichiometric coupling reagents as well as harsh reaction 
conditions, generating a significant amount of waste [18-22]. In this context, new approaches aiming at increasing the atom economy as much as possible could be particularly interesting.

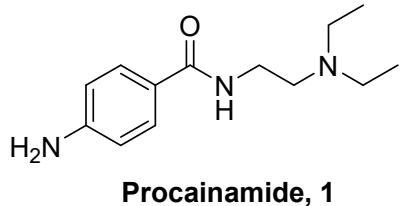

Procainamide, 1

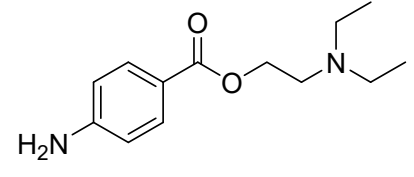

Procaine, 2

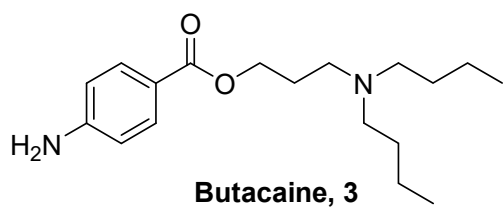

Butacaine, 3

Figure 1. Structures of the target APIs: procainamide (1), procaine (2) and butacaine (3).

\section{Results and Discussion}

To increase the enzyme stability, MsAcT was immobilised onto glyoxyl-agarose support, chosen taking into consideration an in-depth study previously performed by us [17]. Between the selected hydrophilic carriers (i.e., agarose, cellulose, 3-aminopropylic silica, and epoxy resins), the highest recovered activity (i.e., $73 \%)$ was obtained at low enzyme concentration $\left(1 \mathrm{mg} \mathrm{gmatrix}^{-1}\right)$ using activated glyoxyl-agarose as support. Hydrophobic supports have been avoided as they could create non-specific interactions between the enzyme and non-functionalized hydrophobic regions of the carrier. Glyoxyl-agarose allowed the obtainment of a robust catalyst, easy to incorporate to flow chemistry reactors (packed bed reactor, PBR), guaranteeing regular packing and controlled fluid dynamics with consequent more-than-acceptable residence time distribution and process efficiency. Recent attempts on MsAcT immobilisation involved also carbon nanotubes [23] or siliceous monolithic microreactors [24].

In a first set of experiments, ethyl 4-nitrobenzoate was investigated as acyl donor for $\mathrm{N}$ and $\mathrm{O}$-acylation, but no trace of reaction was observed. Since vinyl esters are more efficient acyl donors [16,17], activated vinyl 4-nitrobenzoate 4 was prepared exploiting a $\mathrm{Pd}(\mathrm{II})$-catalysed transvinylation reaction starting from 4-nitrobenzoic acid [25]. First, the solubility of vinyl 4-nitrobenzoate 4 was evaluated in phosphate buffer $(100 \mathrm{mM}, \mathrm{pH}=8)$ in the presence of DMSO as a co-solvent $(10 \% v / v)$ [16]. However, compound 4 resulted only poorly soluble in the mixture, even increasing DMSO up to $20 \% v / v$. Therefore, the reaction was set up in a biphasic system. In particular, the acyl donor 4 was dissolved in toluene $(0.25 \mathrm{M})$ and the nucleophile, i.e., $N^{1}, N^{1}$-diethylethane-1,2-diamine 5, was dissolved in phosphate buffer $(100 \mathrm{mM}, \mathrm{pH}=8)$. The two phases were mixed in a T-piece to form a liquid heterogeneous segmented flow stream before entering the bioreactor kept at $28^{\circ} \mathrm{C}$. After $30 \mathrm{~min}$ of residence time, very low product formation was observed by HPLC (about 10\%) that did not considerably increase when applying longer residence times, i.e., 60 and $120 \mathrm{~min}$. Moreover, a consistent amount of benzoic acid was formed (about $20 \%$ by HPLC). To limit the hydrolysis of vinyl 4-nitrobenzoate 4 and to facilitate the access of the nucleophile, we performed the biotransformation in pure organic solvent, i.e., toluene [26]. Therefore, both the solutions of compound 4 and compound $5(0.25 \mathrm{M}$ and $0.50 \mathrm{M}$, respectively) were prepared in toluene, mixed in a $\mathrm{T}$ piece and directed into the bioreactor (Scheme 1).

Using a $2 \mathrm{~mL}$ bioreactor, different residence times were evaluated (i.e., $5 \mathrm{~min}, 7 \mathrm{~min}$ and $15 \mathrm{~min}$, Table 1) and the reaction outcome was monitored by HPLC. Thanks to the high local concentration of the immobilised biocatalyst in the PBR and to the efficient mixing, using a $0.25 \mathrm{M}$ solution of vinyl 4-nitrobenzoate 4 and 2 equivalents of the nucleophile 5, the reaction reached completion in only 7 min of residence time and no formation of benzoic acid was detectable by HPLC. Notably, in batch, full conversion was achieved after $24 \mathrm{~h}$. Temperature was kept at $28^{\circ} \mathrm{C}$, because no beneficial effects on the conversion have been observed by increasing it. Under these conditions, the specific

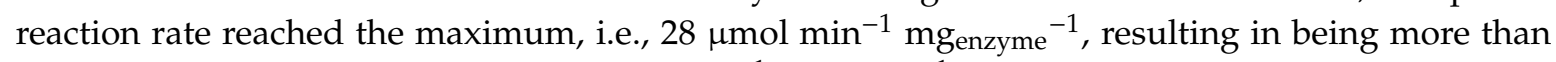
twice the one of the batch reaction $\left(12 \mu \mathrm{mol} \mathrm{min}{ }^{-1} \mathrm{mg}_{\text {enzyme }}{ }^{-1}\right)$. Consequently, to evaluate the stability of the bioreactor, the system was left working for $6 \mathrm{~h}$ under the conditions reported in Table 1, entry 2, and collecting about $200 \mathrm{~mL}$ of solution, monitoring the reaction outcome every $1 \mathrm{~h}$ by HPLC. 
Remarkably, the immobilisation strategy increased the enzymatic stability in pure toluene (average conversion: $97 \%$ ); only at the end of the experiment, a slight decrease in the conversion was observed $(c=95 \%)$. The high performance of the immobilised enzyme in the organic environment might be ascribed to water adsorbed to the glyoxyl-agarose carrier [27]. A previous study reporting the use of the immobilised MsAcT in pure EtOAc was carried out using neopentylglycol as the substrate [24], but the use of EtOAc as solvent and acyl donor at the same time led to the inactivation of the enzyme after $4 \mathrm{~h}$ of continuous work due to the hydrolysis side-reaction with the formation of acetic acid and the consequent $\mathrm{pH}$ drop. Here, the use of toluene as main solvent to dissolve the acyl acceptors and donors reduced the hydrolysis side-reaction of the vinyl ester, thus increasing the overall yields and preserving MsAcT from inactivation due to the low $\mathrm{pH}$.

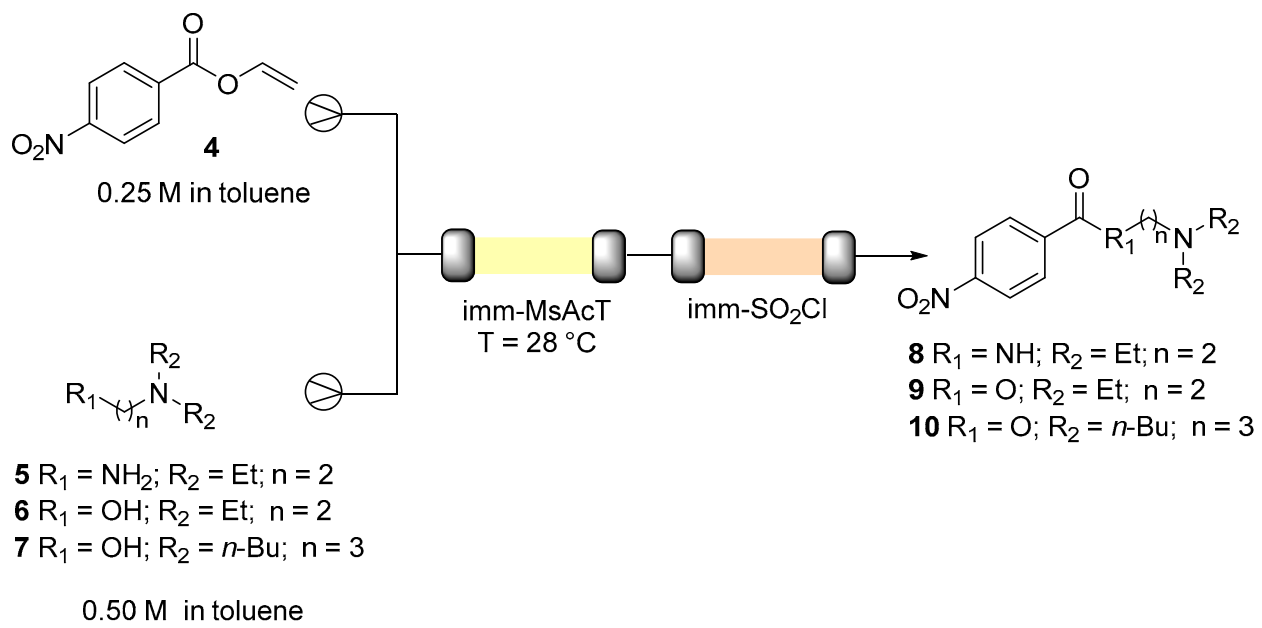

Scheme 1. Reaction conditions: $0.25 \mathrm{M}$ solution of 4 in toluene, $0.5 \mathrm{M}$ solution of the nucleophile $(5,6$, and 7) in toluene; temperature of the bioreactor: $\mathrm{T}=28^{\circ} \mathrm{C}$; flow stream: toluene.

Table 1. Effect of the residence time on the flow synthesis of amide $N$-(2-(diethylamino)ethyl)-4nitrobenzamide (8) catalyzed by immobilised MsAcT ${ }^{\mathrm{a}}$.

\begin{tabular}{|c|c|c|c|}
\hline Entry & Residence Time (min) & Conversion ${ }^{b}(\%)$ & $r\left(\mu \mathrm{mol} \mathrm{min}^{-1} \mathrm{mg}_{\text {enzyme }}{ }^{-1}\right)^{c}$ \\
\hline 1 & 5 & 44 & 18 \\
\hline 2 & 7 & 100 & 28 \\
\hline 3 & 15 & 100 & 13 \\
\hline
\end{tabular}

\footnotetext{
a Experimental conditions: flow stream: toluene; $0.25 \mathrm{M}$ solution of 4 in toluene, $0.5 \mathrm{M}$ solution of 5; reactor volume: $2 \mathrm{~mL}$; immobilised MsAcT: $2.5 \mathrm{~g}$ with an enzyme loading of $1 \mathrm{mg} / \mathrm{g}_{\text {agarose }}$; $\mathrm{T}=28{ }^{\circ} \mathrm{C}$; ${ }^{\mathrm{b}}$ Determined by HPLC. Conversions (\%) are the average of two experiments. ${ }^{c}$ Specific reaction rates $\left(\mu \mathrm{mol} \mathrm{min}^{-1} \mathrm{mg}_{\text {enzyme }}{ }^{-1}\right.$ ) were calculated using the equation: $r=[P] \times f / m_{e}$, where $[P]$ is the concentration of the product $\left(\mu \mathrm{mol} \mathrm{mL}^{-1}\right), \mathrm{f}$ is the flow rate $\left(\mathrm{mL} \mathrm{min}^{-1}\right)$ and $\mathrm{m}_{\mathrm{e}}$ is the amount of enzyme immobilised on the support $(\mathrm{mg})[28,29]$.
}

To obtain the planned APIs and prove the versatility of the system, two other nucleophiles, i.e., 2-(diethylamino)ethanol 6 and 3-(dibutylamino)propan-1-ol 7, have been exploited under optimised conditions (residence time: $7 \mathrm{~min}$; $\mathrm{T}=28^{\circ} \mathrm{C}$ ), using vinyl 4-nitrobenzoate 4 as acyl donor ( 1 eq.). Being the primary alcohols less nucleophilic than the primary amine previously used, a very low conversion was achieved in $7 \mathrm{~min}$ of residence time, using two equivalents of compound 6 or 7 . Then, to achieve higher conversions, we simply increased the residence time, but even after 60 min only $32 \%$ of conversion was obtained. Therefore, the stoichiometry and the residence time were modified (Table 2). The concentration of the nucleophile was increased up to $1 \mathrm{M}$ and different residence times have been tested (i.e., $7 \mathrm{~min}, 15 \mathrm{~min}$ and $30 \mathrm{~min}$, Table 2). The best conversion was achieved by using four equivalents of the nucleophile in $15 \mathrm{~min}$ of residence time (Table 2, entries 4 and 6). A further increase in the residence time was not beneficial (Table 2, entries 5 and 7). 
Table 2. Synthesis of esters $\mathbf{9}$ and $\mathbf{1 0}$ catalyzed by immobilised MsAcT ${ }^{\mathrm{a}}$.

\begin{tabular}{ccccc}
\hline Entry & Nucleophile & Nucleophile Concentration (M) & Residence Time (min) & Conversion $^{\mathbf{b}}(\mathbf{\%})$ \\
\hline 1 & 6 & 0.5 & 7 & 25 \\
2 & 7 & 0.5 & 7 & 15 \\
3 & 6 & 1 & 7 & 32 \\
4 & 6 & 1 & 15 & 72 \\
5 & 6 & 1 & 30 & 74 \\
6 & 7 & 1 & 15 & 36 \\
7 & 7 & 1 & 30 & 37 \\
\hline
\end{tabular}

${ }^{a}$ Experimental conditions: flow stream: toluene; $0.25 \mathrm{M}$ solution of 4 in toluene, reactor volume: $2 \mathrm{~mL}$; immobilised MsAcT: $2.5 \mathrm{~g}$ with an enzyme loading of $1 \mathrm{mg} / \mathrm{g}_{\text {agarose; }} \mathrm{T}=28^{\circ} \mathrm{C} ;{ }^{\mathrm{b}}$ Determined by HPLC. Conversions $(\%)$ are the average of two experiments.

The process was further implemented with an in-line purification procedure using immobilised sulphonyl chloride that was packed into a reactor column connected with the bioreactor (Scheme 1) that efficiently trapped the excess of the nucleophile. In this way, compounds 8, 9 and $\mathbf{1 0}$ were isolated without any further purification, after simple solvent evaporation in moderate to good yields (yields: $93 \%, 68 \%$ and $32 \%$, respectively), thus increasing the automation of the protocol and reducing the time associated with work-up procedures.

The obtained intermediates $\mathbf{8}, \mathbf{9}$ and $\mathbf{1 0}$ were then submitted to a flow hydrogenation reaction using a $10 \% \mathrm{Pd} / \mathrm{C}$ cartridge to reduce the nitro group to aniline. To avoid transesterification reaction of esters 9 and 10 using methanol as the solvent, ethyl acetate was used (Scheme 2). The reduction resulted complete working at $60^{\circ} \mathrm{C}$ and $10 \mathrm{bar}$ at $0.8 \mathrm{~mL} / \mathrm{min}$. The desired APIs, 1, 2, and 3, were isolated after solvent evaporation in quantitative yield.

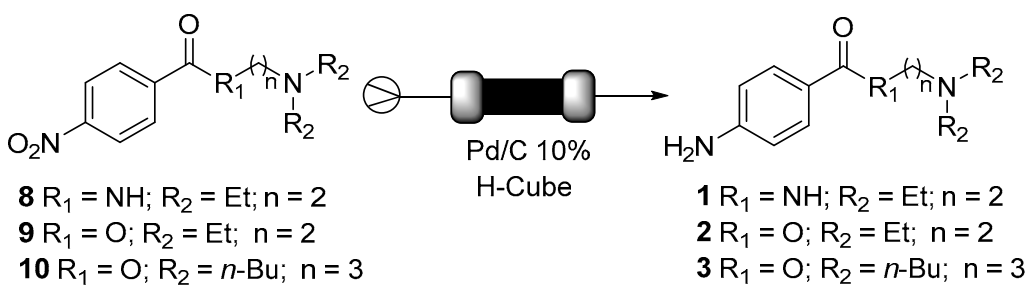

Scheme 2. Synthesis of procainamide (1), procaine (2) and butacaine (3). Reaction conditions: solution of compound 8, 9 and 10 in EtOAc $(50 \mathrm{mg} / \mathrm{mL}), \mathrm{T}=60^{\circ} \mathrm{C}, \mathrm{P}=10$ bar.

\section{Materials and Methods}

All reagents and solvents were purchased from commercial suppliers and were used without further purification. The continuous flow biotransformations were performed using a R2C/R4 flow reactor commercially available from Vapourtec equipped with Omnifit glass columns $(10 \mathrm{~mm}$ i.d. $\times$ $100 \mathrm{~mm}$ length; $6.6 \mathrm{~mm}$ i.d. $\times 100 \mathrm{~mm}$ length). Hydrogenation reactions were performed using an $\mathrm{H}$-Cube Mini Plus reactor (ThalesNano). ${ }^{1} \mathrm{H}$ NMR and ${ }^{13} \mathrm{C}$ NMR spectra were recorded with a Varian Mercury $300(300 \mathrm{MHz})$ spectrometer. Chemical shifts $(\delta)$ are expressed in ppm, and coupling constants $(J)$ are expressed in Hz. TLC analyses were performed using commercial silica gel 60 F254 aluminum sheets. HPLC analyses were performed using Waters 1525 Binary HPLC Pump, equipped with a Waters 2489 UV-vis detector (Waters, Milford, MA) and an Ascentis C18 column $(25 \mathrm{~cm} \times 4 \mathrm{~mm}, 4 \mu \mathrm{m}$ particle size). Protein expression, protein purification and free enzyme activity measurements were performed following previously reported protocols [30]. Agarose gel 6B-CL was activated to glyoxyl-agarose as previously reported [31]. Aldehyde-agarose immobilisation and immobilised MsAcT activity were performed as previously described [17]. 


\subsection{Analytical Method}

Mobile phase: $\mathrm{H}_{2} \mathrm{O}+0.05 \%$ TFA(A)/ACN $+0.05 \%$ (B); gradient conditions: $0-5 \min 80 \%(\mathrm{~A}) / 20 \%$ (B), $5-8 \min 20 \%$ (A)/80\% (B); flow rate: $1.0 \mathrm{~mL} \mathrm{~min}^{-1} ; \lambda: 254 \mathrm{~nm}$. Injection volume: $10 \mu \mathrm{L}$; Reaction samples were diluted with a solution 1:50 $\mathrm{H}_{2} \mathrm{O} / \mathrm{ACN}+0.05 \%$ TFA. Retention times $\left(\mathrm{t}_{\mathrm{R}}\right)$ : 4-nitrobenzoic acid $=5.17 \mathrm{~min}$, vinyl 4-nitrobenzoate $(4)=6.14 \mathrm{~min}, N$-(2-(diethylamino)ethyl)-4-nitrobenzamide $(8)=$ $2.03 \mathrm{~min}$, 2-(diethylamino)ethyl 4-nitrobenzoate $(9)=3.03 \mathrm{~min}$, 3-(dibutylamino)propyl 4-nitrobenzoate (10) $=5.21 \mathrm{~min}$.

\subsection{Synthesis of Vinyl 4-nitrobenzoate (4)}

To a solution of $p$-nitrobenzoic acid $(5.0 \mathrm{mmol})$ in THF $(5 \mathrm{~mL})$, vinyl acetate $(80 \mathrm{mmol}, 7.5 \mathrm{~mL})$ and palladium(II) acetate $(0.5 \mathrm{mmol})$ were added. After degassing, the reaction mixture was stirred for $30 \mathrm{~min}$ at room temperature. Then, $10 \% \mathrm{w} / \mathrm{w}$ of sulfuric acid in THF ( 5 drops) was added and the mixture was stirred at $60^{\circ} \mathrm{C}$ overnight, then filtered through celite. The solvent was evaporated and the crude mixture was purified by column chromatography (cyclohexane/ EtOAc 9:1) as a pale yellow solid. Mp: $74-76{ }^{\circ} \mathrm{C} .{ }^{1} \mathrm{H}$ NMR $\left(300 \mathrm{MHz}, \mathrm{CDCl}_{3}\right): \delta 8.38-8.24(\mathrm{~m}, 4 \mathrm{H}), 7.51(\mathrm{dd}, J=13.9,6.2 \mathrm{~Hz}, 1 \mathrm{H})$, $5.15(\mathrm{dd}, J=13.9,2.0 \mathrm{~Hz}, 1 \mathrm{H}), 4.81(\mathrm{dd}, J=6.2,2.0 \mathrm{~Hz}, 1 \mathrm{H}) ;{ }^{13} \mathrm{C} \mathrm{NMR}\left(75 \mathrm{MHz}, \mathrm{CDCl}_{3}\right): \delta 161.90$, $150.99,141.22,134.45,131.22,123.80,99.61$.

\subsection{Biocatalysed Flow Synthesis of N-(2-(diethylamino)ethyl)-4-nitrobenzamide (8)}

A glass column (6.6 mm i.d.) was packed with $2.5 \mathrm{~g}$ of imm-MsAcT $(1 \mathrm{mg} / \mathrm{g})$. A $0.25 \mathrm{M}$ solution of vinyl 4-nitrobenzoate (4) in toluene and a $0.5 \mathrm{M}$ solution of amine 5 in toluene were prepared. The two solutions $(10 \mathrm{~mL}$ each) were mixed in a T-piece and the resulting flow stream was directed into the bioreactor (packed bed reactor volume: $2.0 \mathrm{~mL}$ ). The temperature was set at $28^{\circ} \mathrm{C}$, at ambient pressure, and the flow rate was set at $143 \mu \mathrm{L} / \mathrm{min}$ for each pump. The exiting flow stream was directed into a column (6.6 $\mathrm{mm}$ i.d.) packed with sulphonyl chloride polymer-bound 70-90 mesh (1.2 g, $2.5-3.0 \mathrm{mmol} / \mathrm{g}$ ). The columns were then washed with $4 \mathrm{~mL}$ of toluene to fully recover the product. The solution was collected and the solvent was evaporated under reduced pressure to isolate amide 8 . Yield: $93 \% .{ }^{1} \mathrm{H}$ NMR $\left(300 \mathrm{MHz}, \mathrm{CDCl}_{3}\right) \delta 8.30-8.25(\mathrm{~m}, 2 \mathrm{H}), 8.00-7.93(\mathrm{~m}, 2 \mathrm{H}), 7.35$ (bs, $\left.1 \mathrm{H}\right), 3.58-3.48$ $(\mathrm{m}, 2 \mathrm{H}), 2.73-2.65(\mathrm{~m}, 2 \mathrm{H}), 2.59(\mathrm{q}, J=7.2 \mathrm{~Hz}, 4 \mathrm{H}), 1.11(\mathrm{t}, J=7.2 \mathrm{~Hz}, 6 \mathrm{H}) .{ }^{13} \mathrm{C} \mathrm{NMR}\left(75 \mathrm{MHz}, \mathrm{CDCl}_{3}\right) \delta$ $165.19,149.55,139.99,128.23,123.78,51.43,47.02,37.03,11.35$.

\subsection{Biocatalysed Flow Synthesis of 2-(diethylamino)ethyl 4-nitrobenzoate (9) and 3-(dibutylamino)propyl 4-nitrobenzoate (10)}

A glass column (6.6 mm i.d.) was packed with $2.5 \mathrm{~g}$ of imm-MsAcT ( $1 \mathrm{mg} / \mathrm{g})$. A $0.25 \mathrm{M}$ solution of vinyl 4-nitrobenzoate (4) in toluene and a $1 \mathrm{M}$ solution of alcohol 6 and 7 in toluene were prepared. The two solutions (10 $\mathrm{mL}$ each) were mixed in a T-piece and the resulting flow stream was directed into the bioreactor (packed bed reactor volume: $2.0 \mathrm{~mL}$ ). The temperature was set at $28^{\circ} \mathrm{C}$, at ambient pressure and the flow rate was set at $67 \mu \mathrm{L} / \mathrm{min}$ for each pump. The exiting flow stream was directed into a column (10 mm i.d.) packed with sulphonyl chloride polymer-bound 70-90 mesh (3.5 g, $2.5-3.0 \mathrm{mmol} / \mathrm{g}$ ). The columns were then washed with $4 \mathrm{~mL}$ of toluene to fully recover the product. The solution was collected and the solvent was evaporated under reduced pressure to isolate the desired ester $\mathbf{9}$ and $\mathbf{1 0}$.

2-(diethylamino)ethyl 4-nitrobenzoate (9) Yield: 68\%. ${ }^{1} \mathrm{H}$ NMR $\left(300 \mathrm{MHz}, \mathrm{CDCl}_{3}\right) \delta 8.28-8.22$ $(\mathrm{m}, 2 \mathrm{H}), 8.20-8.14(\mathrm{~m}, 2 \mathrm{H}), 4.45-4.38(\mathrm{~m}, 2 \mathrm{H}), 2.85-2.80(\mathrm{~m}, 2 \mathrm{H}), 2.63-2.55(\mathrm{~m}, 4 \mathrm{H}), 1.03(\mathrm{t}, J=7.1 \mathrm{~Hz}$, 6H). ${ }^{13} \mathrm{C} \mathrm{NMR}\left(75 \mathrm{MHz}, \mathrm{CDCl}_{3}\right) \delta 164.64,150.46,135.70,130.67,123.47,64.28,50.98,47.80,12.02$.

3-(dibutylamino)propyl 4-nitrobenzoate (10). Yield: 32\%. ${ }^{1} \mathrm{H}$ NMR $\left(300 \mathrm{MHz}, \mathrm{CDCl}_{3}\right) \delta 8.32-8.25$ $(\mathrm{m}, 2 \mathrm{H}), 8.23-8.18(\mathrm{~m}, 2 \mathrm{H}), 4.48-4.40(\mathrm{~m}, 2 \mathrm{H}), 2.62-2.55(\mathrm{~m}, 2 \mathrm{H}), 2.50-2.38(\mathrm{~m}, 4 \mathrm{H}), 2.00-1.87(\mathrm{~m}, 2 \mathrm{H})$, $1.45-1.35(\mathrm{~m}, 4 \mathrm{H}), 1.35-1.22(\mathrm{~m}, 4 \mathrm{H}), 0.89(\mathrm{t}, J=7.2 \mathrm{~Hz}, 6 \mathrm{H}) .{ }^{13} \mathrm{C}$ NMR $\left(75 \mathrm{MHz}, \mathrm{CDCl}_{3}\right) \delta 164.51,150.52$, $135.33,130.70,123.51,63.87,52.65,49.89,26.85,24.74,20.25,13.72$. 


\subsection{Synthesis of Procainamide (1), Procaine (2) and Butacaine (3)}

A solution of compound $\mathbf{8}, \mathbf{9}$ and $\mathbf{1 0}$ was prepared in EtOAc $(50 \mathrm{mg} / \mathrm{mL})$ and was submitted to hydrogenation reaction in a $\mathrm{H}-\mathrm{Cube}$ Mini at $0.8 \mathrm{~mL} / \mathrm{min}, \mathrm{T}=60^{\circ} \mathrm{C}$ and $\mathrm{P}=10$ bar. The solvent was evaporated to obtain the desired products in quantitative yields.

Procainamide (1): ${ }^{1} \mathrm{H}$ NMR $\left(300 \mathrm{MHz}, \mathrm{CDCl}_{3}\right) \delta 7.63-7.57(\mathrm{~m}, 2 \mathrm{H}), 7.20(\mathrm{bs}, 1 \mathrm{H}), 6.64-6.57(\mathrm{~m}, 2 \mathrm{H})$, $4.10(\mathrm{bs}, 2 \mathrm{H}), 3.50-3.40(\mathrm{~m}, 2 \mathrm{H}), 2.70-2.63(\mathrm{~m}, 2 \mathrm{H}), 2.61(\mathrm{q}, J=7.2 \mathrm{~Hz}, 4 \mathrm{H}), 1.04(\mathrm{t}, J=7.2 \mathrm{~Hz}, 6 \mathrm{H})$. ${ }^{13} \mathrm{C}$ NMR $\left(75 \mathrm{MHz}, \mathrm{CDCl}_{3}\right) \delta 169.44,149.80,128.75,123.66,114.03,51.69,47.05,36.76,11.03$.

Procaine (2): ${ }^{1} \mathrm{H}$ NMR $\left(300 \mathrm{MHz}, \mathrm{CDCl}_{3}\right) \delta 7.85-7.79(\mathrm{~m}, 2 \mathrm{H}), 6.64-6.57(\mathrm{~m}, 2 \mathrm{H}), 4.40-4.35(\mathrm{~m}, 2 \mathrm{H})$, $4.15(\mathrm{bs}, 2 \mathrm{H}), 2.90-2.80(\mathrm{~m}, 2 \mathrm{H}), 2.70-2.60(\mathrm{~m}, 4 \mathrm{H}), 1.07(\mathrm{t}, J=7.2 \mathrm{~Hz}, 6 \mathrm{H}) .{ }^{13} \mathrm{C} \mathrm{NMR}\left(75 \mathrm{MHz}, \mathrm{CDCl}_{3}\right) \delta$ $166.61,151.03,131.60,119.48,113.73,62.26,50.82,47.58,11.58$.

Butacaine (3): ${ }^{1} \mathrm{H}$ NMR (300 MHz, $\left.\mathrm{CDCl}_{3}\right) \delta 7.88-7.81(\mathrm{~m}, 2 \mathrm{H}), 6.67-6.60(\mathrm{~m}, 2 \mathrm{H}), 4.35-4.25(\mathrm{~m}, 2 \mathrm{H})$, 4.07 (bs, 2H), 2.65-2.55 (m, 2H), 2.50-2.40 (m, 4H), 1.97-1.84 (m, 2H), 1.50-1.40 (m, 4H), 1.40-1.23 $(\mathrm{m}, 4 \mathrm{H}), 0.90(\mathrm{t}, J=7.2 \mathrm{~Hz}, 6 \mathrm{H}) .{ }^{13} \mathrm{C}$ NMR $\left(75 \mathrm{MHz}, \mathrm{CDCl}_{3}\right) \delta 166.63,150.83,131.54,119.86,113.76$, $62.64,53.71,50.38,28.84,26.19,20.62,14.01$.

\section{Conclusions}

An efficient flow-based biocatalytic protocol characterized by high rates and high substrate loading has been developed for the obtainment of pharmaceutically relevant intermediates. In line with the increasing emphasis placed today on biologically mediated chemical reactions, the system exploits the glyoxyl-agarose covalent immobilisation of MsAcT, a versatile acyltransferase from Mycobacterium smegmatis. Immobilised MsAcT was employed in pure organic solvent (i.e., toluene), demonstrating high stability and reusability, reducing the cost contribution of the biocatalyst preparation to the final product, and making the enzyme useful for different synthetic applications performed in organic solvents. Notably, using a $2 \mathrm{~mL}$ bioreactor (i.e., $2.5 \mathrm{mg}$ of MsAcT), about $6.4 \mathrm{~g}$ of amide 8 were obtained with a productivity of $0.43 \mathrm{~g} \mathrm{~h}^{-1} \mathrm{mg}_{\text {enzyme }}{ }^{-1}$, demonstrating the applicability of the system for gram scale synthesis. Flow processing dramatically accelerated biotransformations making the production of three APIs, i.e., the antiarrhythmic procainamide, and the local anaesthetic drugs procaine and butacaine, easily feasible with a substantial reduction in reaction time $(7-15 \mathrm{~min})$ compared to batch processes $(24 \mathrm{~h})$. In-line purification of the key amide and ester intermediates was added downstream, enhancing the automation of the process. A final hydrogenation step using the $\mathrm{H}$-Cube reactor was further carried out to obtain the desired molecules with excellent yields ( $>99 \%)$ making the process fast, safe and easily handled. Due to the availability of larger packed bed reactors and the robustness of the proposed immobilisation protocol, the applicability on a larger scale seems to be feasible; however, deeper calculations using enzyme activity, stability (cycles) and cost data of the supported enzyme and scavenger are necessary to demonstrate that very high-priced chemicals might be produced economically under such conditions.

Author Contributions: Conceptualization, L.T. and A.P.; methodology, M.L.C., F.A., C.P. and D.B.; investigation, M.L.C., F.A., C.P. and D.B.; resources, L.T. and A.P.; data curation, M.L.C., F.A., C.P., F.M. and D.B.; writing-original draft preparation, F.A., L.T., F.M. and A.P.; writing-review and editing, all the Authors; supervision, L.T. and A.P. All authors have read and agreed to the published version of the manuscript.

Funding: This research received no external funding.

Conflicts of Interest: The authors declare no conflict of interest.

\section{References}

1. Gutmann, B.; Cantillo, D.; Kappe, C.O. Continuous-flow technology-a tool for the safe manufacturing of active pharmaceutical ingredients. Angew. Chem. Int. Ed. 2015, 54, 6688-6728. [CrossRef]

2. Baumann, M.; Baxendale, I.R. The synthesis of active pharmaceutical ingredients (APIs) using continuous flow chemistry. Beilstein J. Org. Chem. 2015, 11, 1194-1219. [CrossRef] 
3. Baumann, M.; Moody, T.S.; Smyth, M.; Wharry, S. A perspective on continuous flow chemistry in the pharmaceutical industry. Org. Process Res. Dev. 2020. [CrossRef]

4. Sheldon, R.A.; Pereira, P.C. Biocatalysis engineering: The big picture. Chem. Soc. Rev. 2017, 46, $2678-2691$. [CrossRef]

5. Sheldon, R.A.; Woodley, J.M. Role of Biocatalysis in Sustainable Chemistry. Chem. Rev. 2018, 118, 801-838. [CrossRef]

6. Sheldon, R.A.; Brady, D. Broadening the Scope of Biocatalysis in Sustainable Organic Synthesis. ChemSusChem 2019, 12, 2859-2881. [CrossRef]

7. Devine, P.N.; Howard, R.M.; Kumar, R.; Thompson, M.P.; Truppo, M.D.; Turner, N.J. Extending the application of biocatalysis to meet the challenges of drug development. Nat. Rev. Chem. 2018, 2, 409-421. [CrossRef]

8. Pinto, A.; Contente, M.L.; Tamborini, L. Advances on whole-cell biocatalysis in flow. Curr. Opin. Green Sustain. Chem. 2020, 25, 100343. [CrossRef]

9. Tamborini, L.; Fernandes, P.; Paradisi, F.; Molinari, F. Flow bioreactors as complementary tools for biocatalytic process intensification. Trends Biotechnol. 2018, 36, 73-88. [CrossRef] [PubMed]

10. Britton, J.; Majumdar, S.; Weiss, G.A. Continuous flow biocatalysis. Chem. Soc. Rev. 2018, 47, 5891-5918. [CrossRef] [PubMed]

11. Thompson, M.P.; Peñafiel, I.; Cosgrove, S.C.; Turner, N.J. Biocatalysis using immobilized enzymes in continuous flow for the synthesis of fine chemicals. Org. Process Res. Dev. 2019, 23, 9-18. [CrossRef]

12. De Vitis, V.; Dall'Oglio, F.; Pinto, A.; De Micheli, C.; Molinari, F.; Conti, P.; Romano, D.; Tamborini, L. Chemoenzymatic synthesis in flow reactors: A rapid and convenient preparation of captopril. Chem. Open 2017, 6, 668-673. [CrossRef]

13. Žnidaršič-Plazl, P. Biotransformations in Microflow Systems: Bridging the Gap between Academia and Industry. J. Flow Chem. 2017, 7, 111-117. [CrossRef]

14. Dall'Oglio, F.; Contente, M.L.; Conti, P.; Molinari, F.; Monfredi, D.; Pinto, A.; Romano, D.; Ubiali, D.; Tamborini, L.; Serra, I. Flow-based stereoselective reduction of ketones using an immobilized ketoreductase/ glucose dehydrogenase mixed bed system. Catal. Commun. 2017, 93, 29-32. [CrossRef]

15. De Vitis, V.; Dall'Oglio, F.; Tentori, F.; Contente, M.L.; Romano, D.; Brenna, E.; Tamborini, L.; Molinari, F. Bioprocess Intensification Using Flow Reactors: Stereoselective Oxidation of Achiral 1,3-diols with Immobilized Acetobacter Aceti. Catalysts 2019, 9, 208. [CrossRef]

16. Contente, M.L.; Tamborini, L.; Molinari, F.; Paradisi, F. Aromas flow: Eco-friendly, continuous, and scalable preparation of flavour esters. J. Flow Chem. 2020, 10, 235-240. [CrossRef]

17. Contente, M.L.; Farris, S.; Tamborini, L.; Molinari, F.; Paradisi, F. Flow-based enzymatic synthesis of melatonin and other high value tryptamine derivatives: A five-minute intensified process. Green Chem. 2019, 21, 3263-3266. [CrossRef]

18. Dalu, F.; Scorciapino, M.A.; Cara, C.; Luridiana, A.; Musinu, A.; Casu, M.; Secci, F.; Cannas, C. A catalyst-free, waste-less ethanol-based solvothermal synthesis of amides. Green Chem. 2018, 20, 375-381. [CrossRef]

19. Rasheed, S.; Nageswar Rao, D.; Siva Reddy, A.; Shankarb, R.; Das, P. Sulphuric acid immobilized on silica gel $\left(\mathrm{H}_{2} \mathrm{SO}_{4}-\mathrm{SiO}_{2}\right)$ as an eco-friendly catalyst for transamidation. RSC Adv. 2015, 5, 10567-10574. [CrossRef]

20. Kelly, S.M.; Lipshutz, B.H. Chemoselective reductions of nitroaromatics in water at room temperature. Org. Lett. 2014, 16, 98-101. [CrossRef] [PubMed]

21. Vardanyan, R.S.; Hruby, V.J. Local Anesthetics in Synthesis of Essential Drugs; Elsevier: Amsterdam, The Netherlands, 2006; pp. 9-18. [CrossRef]

22. Abdullaev, M.G. Development of the method of novocain production. Pharm. Chem. J. 2001, 35, 556-559. [CrossRef]

23. Zoica Dinu, C.; Zhu, G.; Sundhar Bale, S.; Anand, G.; Reeder, P.J.; Sanford, K.; Whited, G.; Kane, R.S.; Dordick, J.S. Enzyme-based nanoscale composites for use as active decontamination surfaces. Adv. Funct. Mater. 2010, 20, 392-398. [CrossRef]

24. Szymańska, K.; Odrozek, K.; Zniszczoł, A.; Torrelo, G.; Resch, V.; Hanefeld, U.; Jarzębski, A.B. MsAcT in siliceous monolithic microreactors enables quantitative ester synthesis in water. Catal. Sci. Technol. 2016, 6, 4882-4888. [CrossRef]

25. Kadidae, L.O.; Usami, A.; Honda, M. Palladium(II) acetate as catalyst in transvinylation reactions of hydroxycinnamic acid and its derivatives. Asian J. Chem. 2018, 30, 589-593. [CrossRef] 
26. Alfonsi, K.; Collberg, J.; Dunn, P.J.; Fevig, T.; Jennings, S.; Johnson, T.A.; Kleine, H.P.; Knight, C.; Nagy, M.A.; Perry, D.A.; et al. Green chemistry tools to influence a medicinal chemistry and research chemistry based organization. Green Chem. 2008, 10, 31-36. [CrossRef]

27. Mathews, I.; Soltis, M.; Saldajeno, M.; Ganshaw, G.; Sala, R.; Weyler, W.; Cervin, M.A.; Whited, G.; Bott, R. Structure of a novel enzyme that catalyzes acyl transfer to alcohols in aqueous conditions. Biochemistry 2007, 46, 8969-8979. [CrossRef]

28. Zambelli, P.; Tamborini, L.; Cazzamalli, S.; Pinto, A.; Arioli, S.; Balzaretti, S.; Plou, F.J.; Fernandez-Arrojo, L.; Molinari, F.; Conti, P.; et al. An efficient continuous flow process for the synthesis of a non-conventional mixture of fructooligosaccharides. Food Chem. 2016, 190, 607-613. [CrossRef]

29. Tamborini, L.; Previtali, C.; Annunziata, F.; Bavaro, T.; Terreni, M.; Calleri, E.; Rinaldi, F.; Pinto, A.; Speranza, G.; Ubiali, D.; et al. An enzymatic flow-based preparative route to vidarabine. Molecules 2020, 25, 1223. [CrossRef]

30. Contente, M.L.; Pinto, A.; Molinari, F.; Paradisi, F. Biocatalytic N-acylation of amines in water using an acyltransferase from Mycobacterium smegmatis. Adv. Synth. Catal. 2018, 360, 4814-4819. [CrossRef]

31. Guisàn, J.M. Aldehyde-agarose gels as activated supports for immobilization-stabilization of enzymes. Enzyme Microb. Technol. 1988, 10, 375-382. [CrossRef]

(C) 2020 by the authors. Licensee MDPI, Basel, Switzerland. This article is an open access article distributed under the terms and conditions of the Creative Commons Attribution (CC BY) license (http://creativecommons.org/licenses/by/4.0/). 